\title{
Article \\ Enhanced Performance of Bioelectrodes Made with Amination-Modified Glucose Oxidase Immobilized on Carboxyl-Functionalized Ordered Mesoporous Carbon
}

\author{
Chuhan Lv ${ }^{1,+}$, Xuewei Yang ${ }^{1, *+}{ }^{\dagger}$, Zongkang Wang ${ }^{2}$, Ming Ying ${ }^{1}$, Qingguo Han ${ }^{1}$ and Shuangfei Li ${ }^{1, *}$ \\ 1 Guangdong Technology Research Center for Marine Algal Bioengineering, Guangdong Key Laboratory of \\ Plant Epigenetics, College of Life Sciences and Oceanography, Shenzhen University, Shenzhen 518060, China; \\ LVCHU0510@163.com (C.L.); yingming@szu.edu.cn (M.Y.); hanqingguoszu@163.com (Q.H.) \\ 2 Shenzhen Batian Ecological Engineering Co., Ltd., Shenzhen 518055, China; wangzongkang712@163.com \\ * Correspondence: yangxw@szu.edu.cn (X.Y.); sfli@szu.edu.cn (S.L.); Tel.: +86-0755-26558939 (X.Y.) \\ + Co-first author.
}

check for updates

Citation: Lv, C.; Yang, X.; Wang, Z.; Ying, M.; Han, Q.; Li, S. Enhanced Performance of Bioelectrodes Made with Amination-Modified Glucose Oxidase Immobilized on Carboxyl-Functionalized Ordered Mesoporous Carbon. Nanomaterials 2021, 11, 3086. https://doi.org/ 10.3390/nano11113086

Academic Editors: Jasmina Vidic and Ivana Gadjanski

Received: 9 October 2021

Accepted: 11 November 2021

Published: 16 November 2021

Publisher's Note: MDPI stays neutral with regard to jurisdictional claims in published maps and institutional affiliations.

Copyright: (C) 2021 by the authors Licensee MDPI, Basel, Switzerland. This article is an open access article distributed under the terms and conditions of the Creative Commons Attribution (CC BY) license (https:/ / creativecommons.org/licenses/by/ $4.0 /)$.

\begin{abstract}
This research reveals the improved performance of bioelectrodes made with aminationmodified glucose oxidase $\left(\mathrm{GOx}-\mathrm{NH}_{2}\right)$ and carboxyl-functionalized mesoporous carbon (OMC$\mathrm{COOH})$. Results showed that when applied with $10 \mathrm{mM}$ EDC amination, the functional groups of $\mathrm{NH}_{2}$ were successfully added to GOx, according to the analysis of ${ }^{1} \mathrm{H}-\mathrm{NMR}$, elemental composition, and FTIR spectra. Moreover, after the aminated modification, increased enzyme immobilization (124.01 $\pm 1.49 \mathrm{mg}$ GOx- $\mathrm{NH}_{2} / \mathrm{g}$ OMC-COOH; 2.77-fold increase) and enzyme activity (1.17-fold increase) were achieved, compared with those of non-modified GOx. Electrochemical analysis showed that aminated modification enhanced the peak current intensity of Nafion/GOx- $\mathrm{NH}_{2} / \mathrm{OMC}$ $\mathrm{COOH}$ (1.32-fold increase), with increases in the charge transfer coefficient $\alpha(0.54)$, the apparent electron transfer rate constant $k_{s}\left(2.54 \mathrm{~s}^{-1}\right)$, and the surface coverage $\Gamma\left(2.91 \times 10^{-9} \mathrm{~mol} \cdot \mathrm{cm}^{-2}\right)$. Results showed that GOx- $\mathrm{NH}_{2} / \mathrm{OMC}-\mathrm{COOH}$ exhibited impressive electro-activity and a favorable anodic reaction.
\end{abstract}

Keywords: carboxylation; chemical amination; glucose oxidase

\section{Introduction}

The combination of nanomaterials and proteins (e.g., enzymes, antibodies, etc.) has been widely used in biosensors, biocatalysis, bioelectronics, biofuels, drug delivery systems, and biomedicine for a long time [1,2]. In order to achieve these applications, they are usually functionalized by various methods or incorporated into a polymer matrix [3-5] in order to ensure that the immobilized biologically active ingredients have better stability and functional density [6]. In particular, improving the interface reaction between the biomolecules and the electrode surface can be considered to be one of the most popular applications of nanomaterials [5], because it is the basis for the construction of biosensors, biomedicines, and other bioelectrochemical systems. The electron transfer of proteins is mainly controlled by three factors [7]: reorganization energies; potential differences and orientations of involved redox-active sites; and distances between redox-active sites and mediators. The effective kinetic barrier for electron transfer is the protein or glycoprotein shell surrounding the active site [8]. Since carbon nanomaterials can promote direct electronic communication between the redox sites of proteins and electrodes, they have become attractive materials for direct electrochemistry of enzymes in bioelectrochemistry [8-10]. Thus, how to improve catalyst efficiency and promote electron transfer between the enzyme redox center and the electrode [6], so as to obtain a biosensor with good performance, merits further exploration [9].

GOx is widely used in the construction of glucose sensors, owing to its high selectivity to glucose and high activity in a wide $\mathrm{pH}$ range [11]. There are amino, carboxyl, and 
hydroxyl groups in the amino acid part of the enzyme, which are used for covalent bonding in the electrode material [12]. The strength of the enzyme-supported multipoint covalent reaction strongly depends on the number of reactive groups [13]. It has been shown that enriching the enzyme surface on the amino surface via different techniques can successfully enhance the process of multipoint covalent immobilization [14]. The purposes of chemical functionalization are as follows [15]: (1) owing to appropriate interactions by surface anchoring specifically, preferentially adsorbed or grafted enzymes produce carbon nanomaterials close to the active site of GOx, improving the electronic transport capacity of the electrode because it provides a good electron-conductive network [2,8-10]; and (2) to increase the load of enzymes, thereby increasing the catalytic current and, finally, enhancing the amount of electroactive enzymes. Moreover, charged functional groups exposed on the nanomaterials' surface can control or guide the protein adsorption [16] through group types [17], hydrophobicity [18], and particle surface charge [19]. Gloria Fernandez-Lorente et al. [20] chemically aminated the lipase of Bacillus thermocatenulatus $\left(\mathrm{BTL}_{2}\right)$, which was covalently immobilized on highly activated acetaldehyde-agarose; the immobilization rate of aminase was higher than that of the natural enzyme at $\mathrm{pH} 10$, and the stability of the immobilized enzyme was improved. Maryam Ashjari et al. [21] chemically aminated Rhizopus oryzae lipase (ROL) and covalently attached it to epoxy-functionalized silica and silica nanoparticles (MCM-41 and SBA-15); the immobilized derivatives of aminated ROL had higher thermal stability and co-solvent stability, and the selectivity and reusability of ROL were greatly improved. Rafael C. Rodrigues et al. [22] covalently linked the lipase of aminated thermophilic mold (TLL) to glyoxylic acid agarose at multiple points and compared it with the unmodified enzyme; the stability of the immobilization of the chemically modified enzyme during the heat inactivation process was improved fivefold. At present, there are many reports on the chemical amination and immobilization of GOx [20-22], but there has only been one report of an electrochemical sensor with chemical amination of laccase-immobilized and -functionalized carbon nanotubes for phenol detection [23]. Moreover, there are few reports on the electrochemical performance of aminated GOx-immobilized functional nanocarbon materials.

For enzymatic bioelectrodes, the immobilization carrier material greatly affects the efficiency of the fuel cell via electrical conductivity and stability range. It has been reported that when using a porous electrode in place of a planar electrode, the power density was increased by $72 \%$, with enhanced effective area and improved material transport characteristics [24]. Compared with other electrode materials, carbon-based materials (such as graphite fiber brush [25], reticulated vitreous carbon (RVC) [26], carbon cloth [27], carbon felt [28], and graphite rods [29]) are more broadly used because of their valuable properties, such as the possibility of chemical surface modification, high electrical conductivity, high biocompatibility, and low prices [30]. Moreover, nanocarbon materials have been successfully used in various electrochemical biosensing schemes, and have shown excellent application prospects in designing new sensing systems and enhancing the performance of biological analysis and detection [31]. Therefore, carbon-based porous nanomaterials such as ordered mesoporous carbon (OMC) have been pursued as promising electrode materials due to their unique properties of small size, large surface area, high conductivity, and high chemical and thermal stability [32]. To improve the effective electron transfer rate, surface modification was applied to arrange the correct electron transfer direction so that the electrode surface was sufficiently close to the center of each active substance $[2,9,30]$. Functionalizing the surface of nanomaterials according to the charge groups (such as $\mathrm{COOH},-\mathrm{NH}_{2}$, etc.) is also conducive to the immobilization of enzymes and the driving force of adsorption (the electrostatic interaction, hydrophobic interaction, or hydrogen bond interaction) [17,33-39]. 


\section{Materials and Methods}

\subsection{OMC Carboxyl Functionalization}

OMC functionalization was performed as described in a previous work [40]. In this oxidation experiment, $1 \mathrm{~g}$ of OMC (pore volume of $0.5 \mathrm{~cm}^{3} \cdot \mathrm{g}^{-1}$, surface area of $150-250 \mathrm{~m}^{2} \cdot \mathrm{g}^{-1}$, 699640; Sigma-Aldrich, Shanghai, China) was added to $30 \mathrm{~mL}$ of the APS solution (2 M ammonium persulfate $\left(\left(\mathrm{NH}_{4}\right)_{2} \mathrm{~S}_{2} \mathrm{O}_{8}\right.$, APS $)$ in $2 \mathrm{M}$ sulfuric acid $\left.\left(\mathrm{H}_{2} \mathrm{SO}_{4}\right)\right)$, stirring at $30 \mathrm{rpm}$ for $24 \mathrm{~h}$ at $50{ }^{\circ} \mathrm{C}$ (utilizing a DF-101S heat-collecting magnetic stirrer (AK $\Lambda$ ZAN, Shanghai, China)). The obtained OMC-COOH was filtered and washed 5 times, and then vacuum-dried overnight at $60^{\circ} \mathrm{C}$.

\subsection{Chemical Amination of Enzymes}

As described in [23], GOx (246 U.mg ${ }^{-1}$, G8032, Solarbio, Beijing, China) was aminated. In short, a combination of $25.0 \mathrm{~mL}$ of non-modified GOx solution $(4 \mathrm{mg} / \mathrm{mL})$ with $25 \mathrm{~mL}$ of $1.0 \mathrm{M}$ ethylenediamine (EDA) solution and $50 \mathrm{mM} \mathrm{N}$-(3-dimethylaminopropyl)- $\mathrm{N}^{\prime}$ ethylcarbodiimide hydrochloride (EDC) was mixed for $1.5 \mathrm{~h}$ at $\mathrm{pH} 4.75$, and then dialyzed 5 times with distilled water at $4{ }^{\circ} \mathrm{C}$ using an ultrafiltration tube (molecular weight cutoff of $50 \mathrm{kDa}$, Thermo Scientific, Waltham, MA, USA). The aminated GOx $\left(\mathrm{GOx}-\mathrm{NH}_{2}\right)$ was stored at $-80^{\circ} \mathrm{C}$, dried under vacuum using a lyophilizer (triad 2.51, LABCONCO, south Kansas City, MO, USA), and stored at $-20^{\circ} \mathrm{C}$ for further use.

\subsection{Enzyme Immobilization on $\mathrm{OMC}-\mathrm{COOH}$}

The immobilization test was carried out by suspending $20 \mathrm{mg}$ of $\mathrm{OMC}-\mathrm{COOH}$ in $0.5 \mathrm{~mL}$ of $0.1 \mathrm{M} \mathrm{pH} 7.0$ PBS buffer containing $10 \mathrm{mg} \cdot \mathrm{mL}^{-1}$ of unmodified GOx or aminated GOx $\left(\mathrm{GOx}-\mathrm{NH}_{2}\right)$ in the centrifuge tube. Then, the mixture was incubated at $10^{\circ} \mathrm{C}$ with stirring at $220 \mathrm{rpm}$ (LYZ-D2403 superimposed shaker, Longyue, Shanghai, China) for $6 \mathrm{~h}$ to reach adsorption equilibrium [41]. After fixation, the enzyme-immobilized materials were centrifuged (75008800 Medifuge Centrifuge, Thermo, Waltham, MA, USA) at 10,000 rpm for $5 \mathrm{~min}$. The supernatant was then removed, dried under vacuum using a lyophilizer (triad 2.51, LABCONCO, south Kansas City, MO, USA), and stored at $-20^{\circ} \mathrm{C}$ for further use. In each set of experiments, three biological replicates were performed.

The quantity of unmodified GOx or aminated GOx immobilized on OMC-COOH particles was determined through the original concentration and terminal concentration of the enzyme via UV spectrophotometry at $450 \mathrm{~nm}$ (EPOCH 2 microplate reader, BioTek, Vermont, USA). The glucose oxidase activity of the enzyme-immobilized composite materials (GOx/OMC-COOH and GOx- $\mathrm{NH}_{2} / \mathrm{OMC}-\mathrm{COOH}$ ) was detected using a glucose oxidase assay kit (BC0695, Solarbio, Beijing, China). In each set of experiments, three biological replicates were performed.

\subsection{Inactivation of $\mathrm{GO} x / \mathrm{OMC}-\mathrm{COOH}$ and $\mathrm{GO} x-\mathrm{NH}_{2} / \mathrm{OMC}-\mathrm{COOH}$}

The immobilized enzyme samples obtained after lyophilization were each immersed in $0.1 \mathrm{M} \mathrm{pH} 7.0 \mathrm{PBS}$ buffer and placed in a water bath at $4{ }^{\circ} \mathrm{C}, 10^{\circ} \mathrm{C}, 25^{\circ} \mathrm{C}, 37^{\circ} \mathrm{C}$, or $50{ }^{\circ} \mathrm{C}$ for $2 \mathrm{~h}$ to measure the effect of temperature on their activity. Then, samples were immersed in $0.1 \mathrm{M} \mathrm{pH} 4.4,5.4,6.4,7.4$, or 8.4 PBS buffer solution and incubated in a water bath at $25^{\circ} \mathrm{C}$ for $2 \mathrm{~h}$, and the effect of $\mathrm{pH}$ on their activity was measured. A single obtained immobilized enzyme sample was immersed in $0.1 \mathrm{M} \mathrm{pH} 7.4 \mathrm{PBS}$ buffer solution and incubated at $25^{\circ} \mathrm{C}$ for $6 \mathrm{~h}$ at room temperature to measure the effect of time $(0,0.5,1,1.5,2,4,6 \mathrm{~h})$ on its activity. In each set of experiments, three biological replicates were performed.

\subsection{Fabrication of GOx/OMC-COOH and $\mathrm{GO} x-\mathrm{NH}_{2} / \mathrm{OMC}-\mathrm{COOH}$ Bioelectrodes}

The enzyme bioelectrode was made by sonicating $2 \mathrm{mg}$ of GOx/OMC-COOH and GOx- $\mathrm{NH}_{2} / \mathrm{OMC}-\mathrm{COOH}$ with $150 \mu \mathrm{L}$ of $\mathrm{pH} 7.0 \mathrm{PBS}$ buffer solution (containing $6 \mu \mathrm{L}$ of $0.5 \%$ Nafion) for $5 \mathrm{~min}$ and pipetting a $70 \mu \mathrm{L}$ dispersion onto the carbon cloth as the anode [1]. The carbon cloth electrodes coated with Nafion/GOx/OMC-COOH and Nafion/GOx- 
$\mathrm{NH}_{2}$ /OMC-COOH were placed in a fume hood for $4 \mathrm{~h}$, then rinsed carefully with $\mathrm{pH} 7.0$ PBS buffer and stored at $4{ }^{\circ} \mathrm{C}$ before use.

The elemental composition of the $\mathrm{C}, \mathrm{H}$, and $\mathrm{N}$ contents of the GOx and GOx- $\mathrm{NH}_{2}$ were determined using an organic element analyzer (Vario MICRO Cube, Elementar, Germany). The $\mathrm{N}-\mathrm{H}$ spectra of GOx and GOx- $\mathrm{NH}_{2}$ were measured using a nuclear magnetic resonance instrument (AVANCEIII $400 \mathrm{MHz}$, Bruker, Switzerland) to explore the change in their chemical shift. Fourier-transform infrared spectroscopy (FTIR, Nicolet 6700 , Nicolet, Thermo Fisher Scientific, Waltham, MA, USA) was used to determine the changes in the functional groups of $\mathrm{GOx}$ and $\mathrm{GOx}-\mathrm{NH}_{2}$; the measurement range was $400-4000 \mathrm{~cm}^{-1}$. Electrochemical experiments were performed at room temperature in PBS buffer in the absence and presence of glucose. The impedance EIS was measured at $5 \mathrm{mM}$ $\mathrm{K}_{3}\left[\mathrm{Fe}(\mathrm{CN})_{6}\right] / \mathrm{K}_{4}\left[\mathrm{Fe}(\mathrm{CN})_{6}\right]$ in $0.1 \mathrm{M} \mathrm{KCl}$ solution (frequency range: $10^{-2}-10^{-5} \mathrm{~Hz}$ ) [42].

\section{Results}

\subsection{The Effect of Amination on Enzyme Immobilization}

In order to determine the influence of the amino group on the enzyme surface, an adsorption study was carried out and the concentration of the supernatant was measured in the solution before and after the adsorption equilibrium to quantify the adsorption capacity (Figure 1). This revealed an interesting correlation between the porous network of the carbon materials and the immobilization of the enzyme. In this experiment, the loading amount of the aminated $\mathrm{GOx}\left(\mathrm{GOx}-\mathrm{NH}_{2}\right)$ was $2.48 \mathrm{mg}$ of enzyme $/ 20 \mathrm{mg}$ of OMC-COOH. It was observed that the amount of aminated GOx adsorbed on $\mathrm{OMC}-\mathrm{COOH}$ was 2.77 times higher than that of unmodified GOx on OMC-COOH. These results indicated that when increasing the protein-supported multipoint attachment with aminated groups [43], the protein was fixed more on the OMC-COOH. Gloria Fernandez-Lorente et al. [20] chemically aminated the lipase from Bacillus thermocatenulatus, which can be fixed more easily on glyoxyl-agarose, and is more stable than natural enzymes. Maryam Ashjari et al. [21] chemically aminated Rhizopus oryzae lipase; compared with the non-aminated enzyme, it was able to immobilize a higher number of enzymes on epoxy-functionalized silica and silica nanoparticles. Wilson et al. used a chemical amination method to enrich the surface amino groups of Geotrichum candidum lipase and immobilize it on a carrier based on carboxymethyl and sulfopropyl agarose-based supports, which increased fish oil hydrolysis by 2.40 -fold and 3.20 -fold, respectively [44].

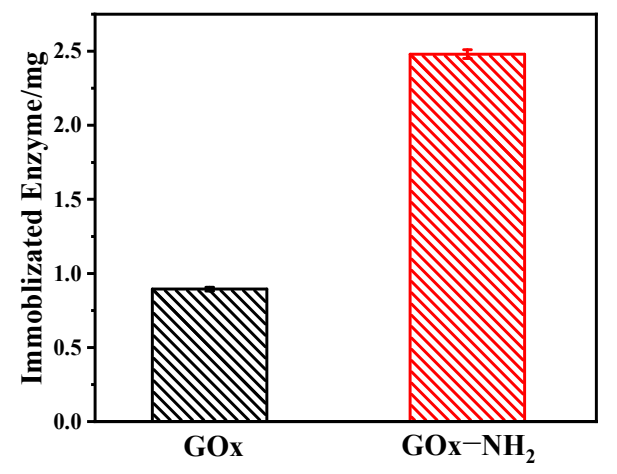

Figure 1. Adsorption capacity of unmodified GOx (black) and aminated GOx (red) on OMC-COOH.

The free GOx- $\mathrm{NH}_{2}$ kept $87.23 \%$ of its activity compared to the free unmodified GOx, indicating that after the chemical reactions to add the aminated groups, the glucose oxidase maintained its activity well. Since the ion bridge may be slightly destroyed and changed by the repulsive force, the modification can decrease the activity of the enzyme to a certain extent [45]. In addition, Table 1 shows that although chemical amination made the unit enzyme activity low, the total enzyme amount adsorbed by the material increased significantly - the total enzyme amount of GOx- $\mathrm{NH}_{2}$ immobilized on OMC-COOH was 
1.77 times greater than that of GOx immobilization. This shows that the total enzyme activity of GOx- $\mathrm{NH}_{2} / \mathrm{OMC}-\mathrm{COOH}$ is relatively high (after calculation, the significant difference $p=0.040$, which is less than 0.050 , so the enzyme activity of the two enzymecarbon composite materials is significantly different). As mentioned above, amination may increase the chemical reactivity by enriching the amount of immobilized enzyme [46], thereby increasing the enzyme activity of the enzyme-containing composite material.

Table 1. Enzyme activity of free enzyme or enzyme immobilized in COOH-OMC.

\begin{tabular}{cccc}
\hline Type & $\begin{array}{c}\text { Quantity of the } \\
\text { Immobilized Enzyme } \\
\text { (GOx mg/OMC } \mathbf{~})\end{array}$ & $\begin{array}{c}\text { Immobilized } \\
\text { Enzyme Activity } \\
\text { (U/g) }\end{array}$ & $\begin{array}{c}\text { Unit Free } \\
\text { Enzyme Activity } \\
\text { (U/mg) }\end{array}$ \\
\hline GOx & $/$ & $/$ & $417.74 \pm 22.22$ \\
GOx-NH 2 & $/$ & $/$ & $364.41 \pm 4.44$ \\
GOx/OMC-COOH & $44.72 \pm 0.88$ & $58,290.47 \pm 3055.42$ & $1303.52 \pm 68.33$ \\
GOx-NH $2 / \mathrm{OMC}-\mathrm{COOH}$ & $124.01 \pm 1.49$ & $67,956.17 \pm 4687.75$ & $547.97 \pm 37.80$ \\
\hline
\end{tabular}

\subsection{Characterization of Aminase}

\subsection{1. ${ }^{1} \mathrm{H}$ NMR Spectral Analysis}

The ${ }^{1} \mathrm{H}$ NMR spectra of the enzymes with unmodified GOx and aminated GOx (Figure 1) allowed the assignment of the H-5 protons in the samples. H-5 in samples with carboxylic acid groups (the ester groups) was found around $4.8 \mathrm{ppm}$ [47]. The signal at $3.8 \mathrm{ppm}$ corresponded exclusively to the anomeric protons, $\mathrm{H}-1_{\mathrm{OH}}$ (Figure 2; black line) [47], while the other protons represented by the red line in Figure 2 appeared as new signals at $\sim 3.3 \mathrm{ppm}$, which may have been caused by the amination reaction. Tightly bound ligand molecules alter the binding site on the protein, and the chemical shifts in the protein resonances typically exhibit the largest chemical shift changes. The result of ${ }^{1} \mathrm{H}$ NMR analysis indicated that the aminated groups were successfully added to GOx.

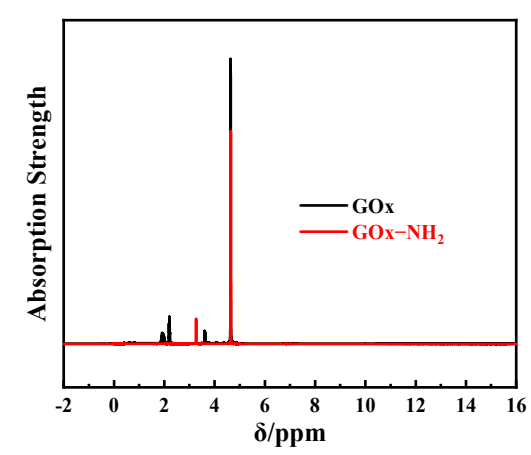

(a)

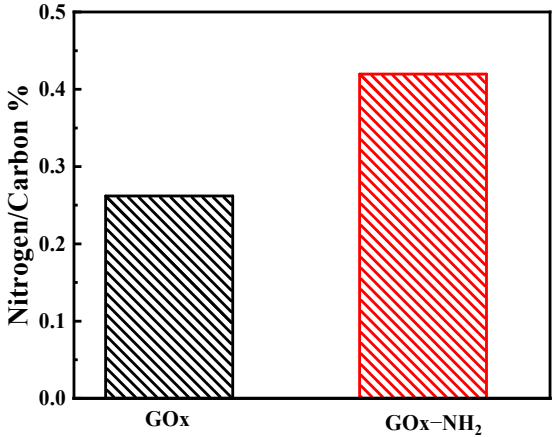

(b)

Figure 2. (a) ${ }^{1} \mathrm{D}^{1} \mathrm{H}$ NMR spectra of unmodified GOx (black) and aminated GOx (red). (b) Elemental analysis results of GOx (black) and aminated GOx (red).

\subsubsection{Element Composition Analysis}

The results of elemental analysis are listed in Figure $2 b$. The hydrocarbon ratio $(\mathrm{N} / \mathrm{C})$ of aminated GOx was significantly higher than that of unmodified GOx, indicating the successful addition of $\mathrm{NH}_{2}$ to the glucose oxidase. Solid EDC was added to the suspension at $10 \mathrm{mM}$ as a final concentration to ensure that all exposed carboxyl groups of the protein were completely modified $[20,48]$. The increase in the ratio of nitrogen to carbon could be the result of enzyme amination. 


\subsubsection{Fourier-Transform Infrared (FTIR) Spectrum Analysis}

The FTIR spectrum results of GOx and GOx- $\mathrm{NH}_{2}$ can be seen in Figure 3. The peak near $3085 \mathrm{~cm}^{-1}$ in the spectra of GOx and GOx- $\mathrm{NH}_{2}$ belongs to asymmetric $\mathrm{CH}_{3}$ stretching, the peak at $2935 \mathrm{~cm}^{-1}$ belongs to asymmetric $\mathrm{CH}_{2}$ stretching, the peak at $2875 \mathrm{~cm}^{-1}$ belongs to symmetric $\mathrm{CH}_{3}$ stretching, and the peak at $1080 \mathrm{~cm}^{-1}$ can be attributed to the stretching of C-O $[49,50]$. The bands of the amide I and II peaks of GOx are located at $1639 \mathrm{~cm}^{-1}$ and $1546 \mathrm{~cm}^{-1}$, respectively, while the bands of the amide I and II peaks of GOx- $\mathrm{NH}_{2}$ are located at $1654 \mathrm{~cm}^{-1}$ and $1539 \mathrm{~cm}^{-1}$, respectively [51,52]. The amide III peak is also located near 1350-1200 $\mathrm{cm}^{-1}$ [51], and the bands of the amide III peaks of GOx and GOx- $\mathrm{NH}_{2}$ are located at $1259 \mathrm{~cm}^{-1}$ and $1267 \mathrm{~cm}^{-1}$, respectively. At $1452 \mathrm{~cm}^{-1}$ and $1400 \mathrm{~cm}^{-1}$, is the peaks are attributed to the shear of the side-chain $\mathrm{CH}_{2}$ and the tensile vibration of $\mathrm{C}-\mathrm{O}$ in $=\mathrm{CO}$, respectively $[49,53]$. The peak at $3290 \mathrm{~cm}^{-1}$ can be attributed to the $\mathrm{N}-\mathrm{H}$ vibration of glucose oxidase [53,54]. In the results of the spectral analysis, although some peak positions were shifted, the peak intensity and peak area of the amide in the $\mathrm{GOx}-\mathrm{NH}_{2}$ spectrum were stronger than those of GOx, clearly showing that the aminase treatment increases the content of $-\mathrm{NH}_{2}$ [43].

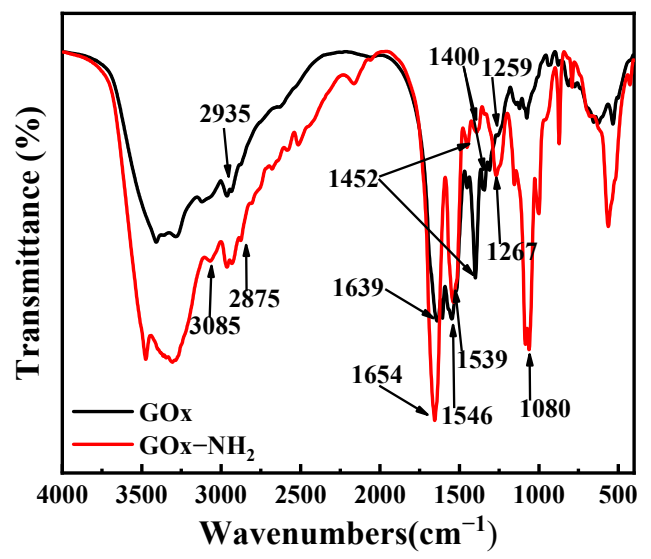

Figure 3. Fourier-transform infrared (FTIR) spectra of unmodified GOx and GOx- $\mathrm{NH}_{2}$.

\subsection{The Effect of Amination on Enzyme Immobilization}

3.3.1. Temperature

For the GOx and GOx- $\mathrm{NH}_{2}$ immobilized on the $\mathrm{OMC}-\mathrm{COOH}$, the modification by amination slightly changed the enzyme activity (Figure 4a). The activity of the unmodified and aminated glucose oxidase at $4{ }^{\circ} \mathrm{C}$ and $10{ }^{\circ} \mathrm{C}$ was almost the same, but it gradually increased with the increase in the reaction temperature, showing the maximum enzyme activity at $37^{\circ} \mathrm{C}$, which is the normal body temperature. This indicates that the GOx- $\mathrm{NH}_{2}$ immobilized on the OMC-COOH possesses great potential and advantages for work involving the physiological fluids of the human body. When the temperature was increased by $50{ }^{\circ} \mathrm{C}$, the activity of the immobilized enzyme decreased, but the activity of the immobilized enzyme after amination was higher than that of the untreated immobilized enzyme, indicating that modification via amination could improve the tolerance of glucose oxidase to high temperatures.

\subsubsection{Buffer $\mathrm{pH}$}

The effect of $\mathrm{pH}$ on the stability of GOx and $\mathrm{GOx}-\mathrm{NH}_{2}$ was determined by incubating the same amounts of the enzymes in $0.1 \mathrm{M} \mathrm{pH} 4.4,5.4,6.4,7.4$, and 8.4 PBS buffer at $25^{\circ} \mathrm{C}$ for $2 \mathrm{~h}$ (Figure $4 \mathrm{~b}$ ). The optimal $\mathrm{pH}$ value of immobilized GOx and $\mathrm{GOx}-\mathrm{NH}_{2}$ was 6.4. When the $\mathrm{pH}$ was 7.4, the immobilized GOx and $\mathrm{GOx}-\mathrm{NH}_{2}$ retained $90.87 \%$ and $89.53 \%$ of the enzyme activity, respectively. Even when the $\mathrm{pH}$ increased to 8.4 , the enzyme activity still retained $84.52 \%$ and $84.29 \%$ of the activity of immobilized GOx and GOx- $\mathrm{NH}_{2}$, 
respectively. Both the immobilized GOx and GOx- $-\mathrm{NH}_{2}$ showed excellent stability in the measured $\mathrm{pH}$ range (4.4-8.4).

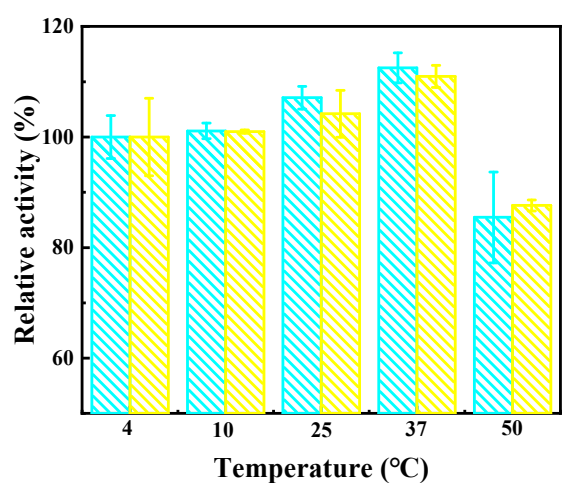

(a)

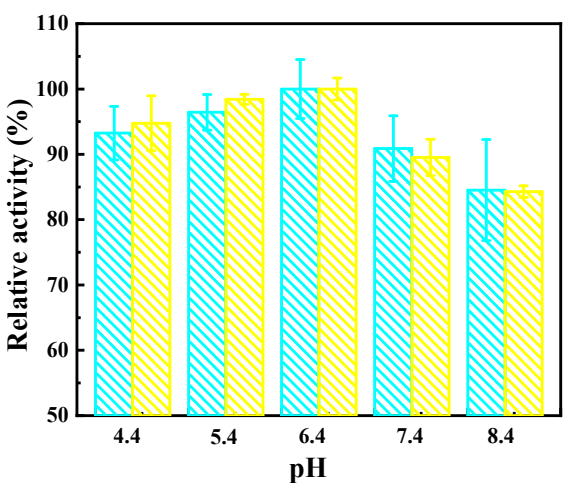

(b)

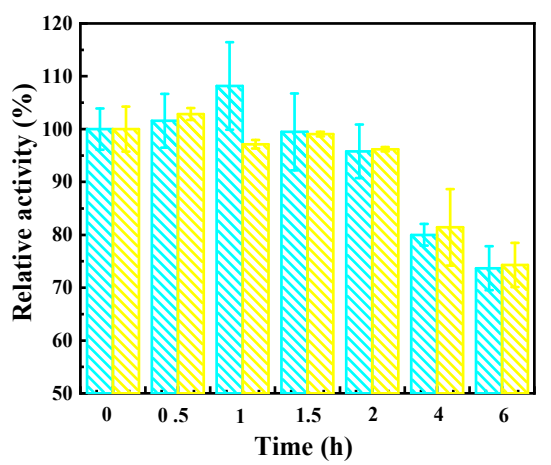

(c)

Figure 4. The effects of temperature (a), buffer $\mathrm{pH}(\mathbf{b})$, and time (c) on the enzyme activities of GOx/OMC-COOH (blue) and GOx- $\mathrm{NH}_{2} / \mathrm{OMC}-\mathrm{COOH}$ (yellow).

\subsubsection{Time}

At room temperature $\left(25^{\circ} \mathrm{C}\right)$, the enzyme activity of the GOx and GOx- $\mathrm{NH}_{2}$ on OMC$\mathrm{COOH}$ was measured over the course of $6 \mathrm{~h}$ (Figure 4c). The results showed that GOx and GOx- $\mathrm{NH}_{2}$ possessed good stability at $0-2 \mathrm{~h}$, and retained $96.19 \%$ and $95.79 \%$ of their initial activity, respectively, at $2 \mathrm{~h}$. As the time went by, the activities of GOx/OMC-COOH and GOx- $\mathrm{NH}_{2} / \mathrm{OMC}-\mathrm{COOH}$ decreased slowly. After $6 \mathrm{~h}$, the residual activities of immobilized GOx and GOx- $-\mathrm{NH}_{2}$ were reduced to $73.68 \%$ and $74.29 \%$, respectively. It was observed that the activity of the immobilized enzyme after amination was higher than that of the untreated immobilized enzyme, indicating that the stability of the modified enzyme is slightly higher.

\subsection{Direct Electrochemistry of Nafion/GOx/OMC-COOH and Nafion/GOx- $\mathrm{NH}_{2} /$ $\mathrm{OMC}-\mathrm{COOH}$ Bioelectrodes}

The Nyquist plot of the impedance spectrum includes a linear portion at low frequency and a semicircle portion at high frequency [11]; the former corresponds to the diffusion process, and the latter corresponds to the charge-transfer-limited process [11]. The electron transfer resistance $\left(R_{c t}\right)$ at the electrode surface is equal to the diameter of the semicircle, which can be used to describe the interface characteristics of the electrode [11,55]. Figure 5 shows the impedance spectra—represented as Nyquist plots (Z" versus Z') —of electrodes modified with GOx/OMC- $\mathrm{COOH}$ and GOx- $\mathrm{NH}_{2} / \mathrm{OMC}-\mathrm{COOH}$ in equimolar $\mathrm{K}_{3}\left[\mathrm{Fe}(\mathrm{CN})_{6}\right] / \mathrm{K}_{4}\left[\mathrm{Fe}(\mathrm{CN})_{6}\right]$ solution. After immobilization of GOx or GOx- $\mathrm{NH}_{2}$ onto $\mathrm{OMC}-\mathrm{COOH}$, the diameter of the high-frequency semicircle increased further $(\mathrm{b}$ and $\mathrm{c}$ in Figure 5). The $R_{c t}$ diminutions of the enzyme electrodes were in the following order: 
$\mathrm{GOx}-\mathrm{NH}_{2} / \mathrm{OMC}-\mathrm{COOH} \approx \mathrm{GO} / \mathrm{OMC}-\mathrm{COOH}>$ bare OMC-COOH . The observed increase in diameter was due to the $\mathrm{GOx}$ or $\mathrm{GOx}-\mathrm{NH}_{2}$ layer acting as a barrier to the charge transfer between the redox probes and the electrode surface in the solution [56]. The non-conductive properties of unmodified GOx or GOx- $\mathrm{NH}_{2}$ hinder the diffusion of the redox couple to the electrode surface, thereby reducing the electron transfer. Meanwhile, the decline in the slope of straight lines substantiates the successful fixation of unmodified GOx or GOx$\mathrm{NH}_{2}$ on the bionanohybrid composite, which slightly reduces the diffusion process of the matrix [55]. These results indicate that unmodified GOx or GOx- $\mathrm{NH}_{2}$ was steadily immobilized onto the OMC-COOH surface [57].

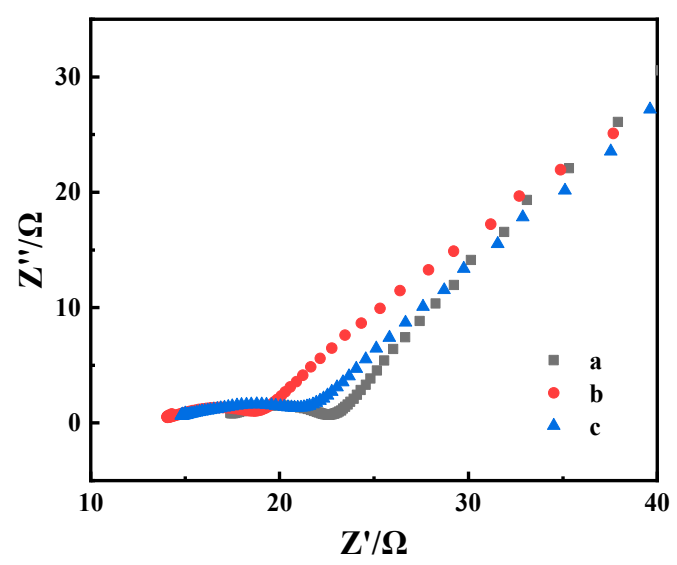

Figure 5. Nyquist plots (- $Z^{\prime \prime}$ vs. $\left.Z^{\prime}\right)$ of Nafion/OMC-COOH (a), Nafion/GOx/OMC-COOH (b), and Nafion/GOx- $\mathrm{NH}_{2} / \mathrm{OMC}-\mathrm{COOH}$ (c).

Under the same conditions, without the existence of the enzyme, naked OMC-COOH (a in Figure 6) scarcely reveals any peak values within the measurement range, which indicates that OMC and Nafion are inert; thus, the generation of current is completely dependent on the activity and amount of immobilized non-modified GOx or GOx- $\mathrm{NH}_{2}$ [58]. However, the redox signal increased as a result of modifying the electrode surface, in the following order: Nafion/GOx- $\mathrm{NH}_{2} / \mathrm{OMC}-\mathrm{COOH}>\mathrm{Nafion} / \mathrm{GOx} / \mathrm{OMC}-\mathrm{COOH}>$ Nafion/OMC-COOH. As shown in $\mathrm{b}$ and $\mathrm{c}$ in Figure 6 , the peak separation $\left(\Delta \mathrm{E}_{\mathrm{p}}\right)$ of the bioanode was b for Nafion/GOx/OMC-COOH and Nafion/GOx-NH $/$ OMC-COOH, at scan rate of $50 \mathrm{mV} \cdot \mathrm{s}^{-1}$, exhibiting a fast electron transfer process. Thus, a direct electron transfer of GOx or GOx- $\mathrm{NH}_{2}$ in the nanocomposite electrodes was achieved via the successful fixation of the enzyme on the surface of OMC-COOH [59]. Compared with the bare electrode, the oxidation current increased as the fixed amount of unmodified GOx or $\mathrm{GOx}-\mathrm{NH}_{2}$ on the surface of the electrode increased. This shows that the redox and electrocatalytic activity of the functionalized enzyme on the electrode surface creates more active sites for catalysis of the redox reaction. This result shows that with the presence of the $\mathrm{NH}_{2}$ group, the surface of Nafion/GOx- $\mathrm{NH}_{2} / \mathrm{OMC}-\mathrm{COOH}$ shows a significant advantage in terms of effective electron transfer efficiency, and builds a conductive and biocompatible microenvironment, which might play an important role in the appropriate enzyme orientation and promote the electron transfer efficiency between aminated GOx and the OMC-COOH electrode [60].

The cyclic voltammogram performed on the bare OMC-COOH electrode, in the absence and presence of glucose, is shown in Figure 7A, while those of Nafion/GOxOMC$\mathrm{COOH}$ and Nafion/GOx- $\mathrm{NH}_{2} / \mathrm{OMC}-\mathrm{COOH}$ are shown in Figure $7 \mathrm{~B}, \mathrm{C}$, respectively. In the absence and presence of glucose, as shown in Figure 7A, there was no obvious peak corresponding to the glucose oxidation in the electrode Nafion/COOH-OMC (a,b), indicating that there was no biochemical reaction on the bare $\mathrm{COOH}-\mathrm{OMC}$ to produce electrons [58]. Thus, the currents observed in the Nafion/GOx/OMC-COOH and Nafion/GOx$\mathrm{NH}_{2}$ /OMC-COOH bioelectrodes were mainly contributed by the GOx catalysis. As Figure $7 \mathrm{C}(\mathrm{e}, \mathrm{f})$ shows, the oxidation peak current of Nafion/GOx- $\mathrm{NH}_{2} / \mathrm{OMC}-\mathrm{COOH}$ was 
much higher (1.21 times) than that of Nafion/GOxOMC-COOH without glucose (Figure 7B $(\mathrm{c}, \mathrm{f}))$, suggesting that it had better electrocatalytic activity. This relative increase indicates that amination could help to improve enzyme attachment onto the electrode surface.

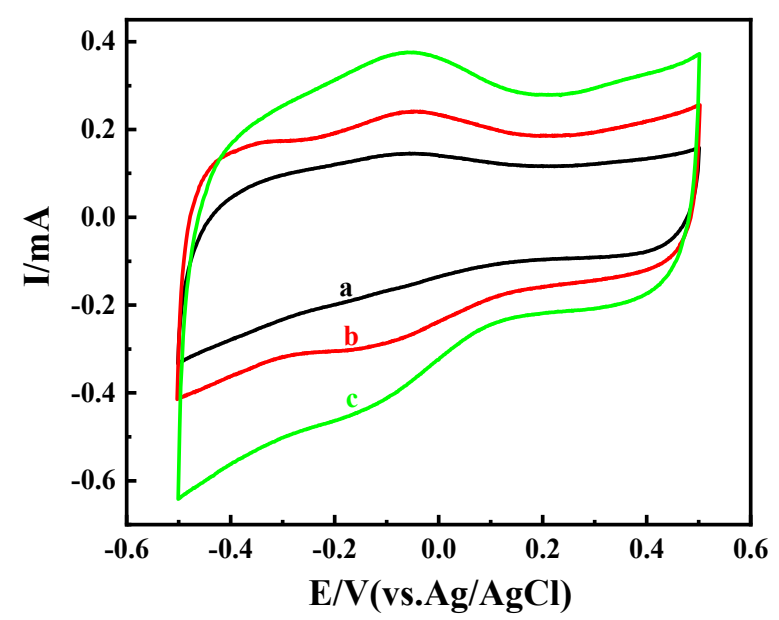

Figure 6. CVs $\left(50 \mathrm{mV} \cdot \mathrm{s}^{-1}\right)$ of Nafion/OMC-COOH (a), Nafion/GOx/OMC-COOH (b), and Nafion/ GOx- $\mathrm{NH}_{2} / \mathrm{OMC}-\mathrm{COOH}$ (c) in air-saturated PBS (0.1 M pH 7.4) without glucose.

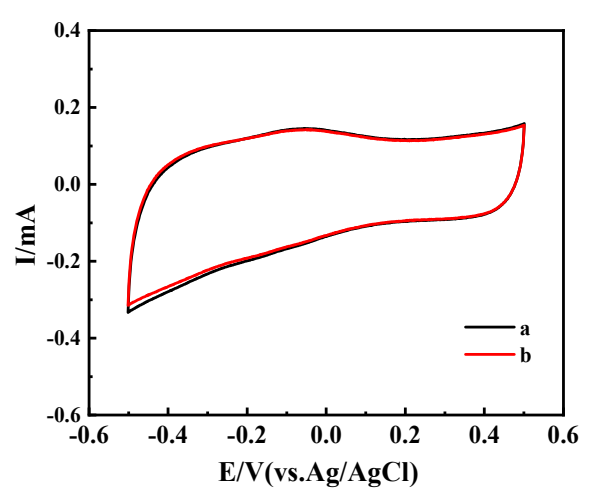

(A)

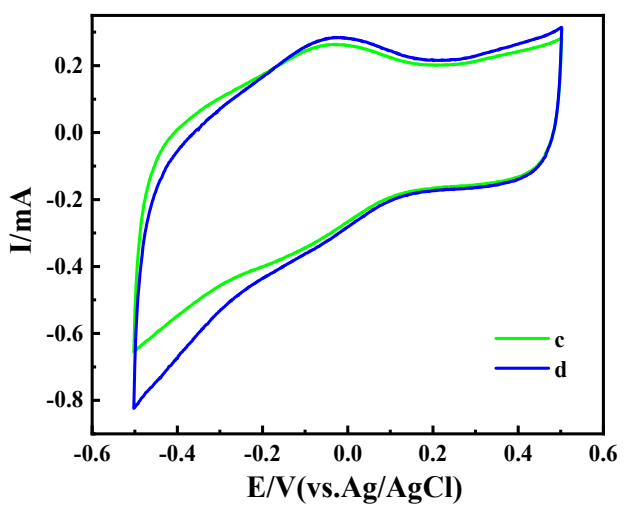

(B)

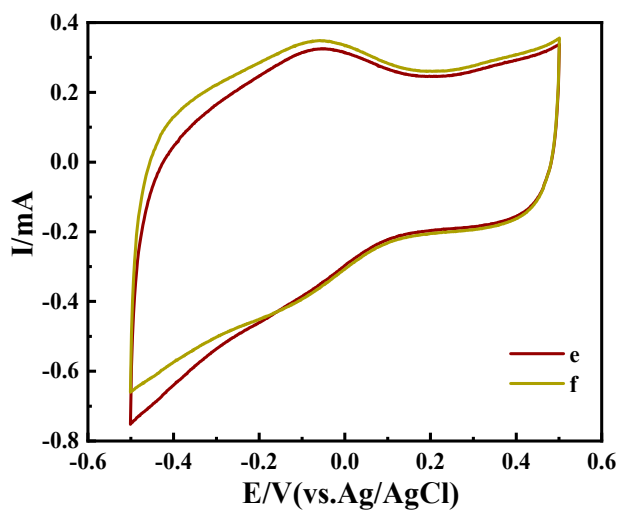

(C)

Figure 7. $\mathrm{CVs}\left(50 \mathrm{mV} \cdot \mathrm{s}^{-1}\right)$ of Nafion/OMC-COOH (A), Nafion/GOx/OMC-COOH (B), and Nafion/GOx-NH $/ \mathrm{OMC}_{2} \mathrm{COOH}$ (C) in air-saturated PBS $0.1 \mathrm{M} \mathrm{pH} 7.4$ without (a,c,e, respectively)/with (b,d,f, respectively) the addition of $20 \mathrm{mM}$ glucose.

The CVs of Nafion/GOx/OMC-COOH and Nafion/GOx- $\mathrm{NH}_{2} / \mathrm{OMC}-\mathrm{COOH}$ at different scan rates $\left(20-150 \mathrm{mV} \cdot \mathrm{s}^{-1}\right)$ in PBS buffer are also shown in Figure 8 . The anodic and cathodic peak currents of the Nafion/GOx/OMC-COOH and Nafion/GOx- $\mathrm{NH}_{2} / \mathrm{OMC}-$ 
$\mathrm{COOH}$ redox system increased linearly with an increase in scan rates. As shown in Figure 8 $\left(A_{1}\right.$ and $\left.B_{1}\right)$, the peak currents had a linear relationship with the square root of the scan rate, indicating that diffusion limitations occur via the electrode layer [61], which contributes to the surface processes of Nafion/GOx/OMC-COOH and Nafion/GOx- $\mathrm{NH}_{2} / \mathrm{OMC}-\mathrm{COOH}$. For applications of nano-composite carbon nanotube-platinum carbon nanoparticles in glucose biosensing [62], similar electrochemical behavior was also observed.

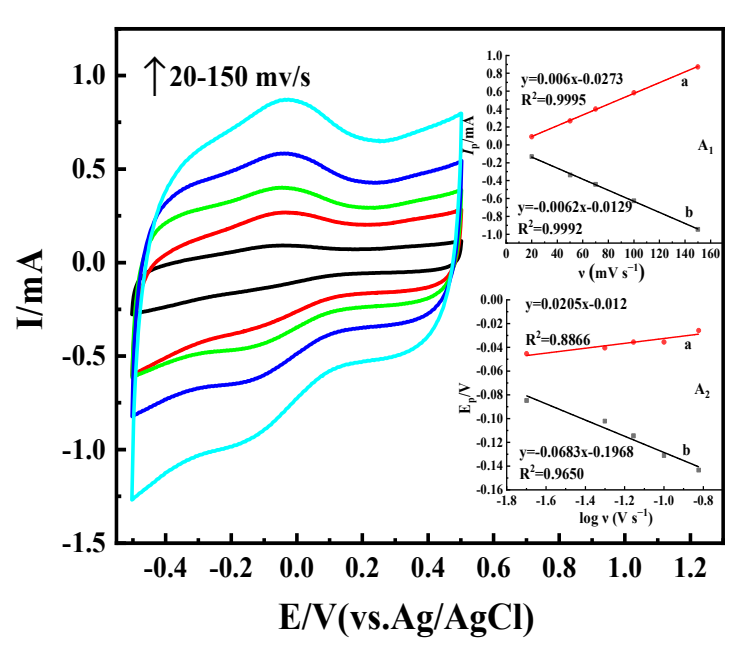

(a)

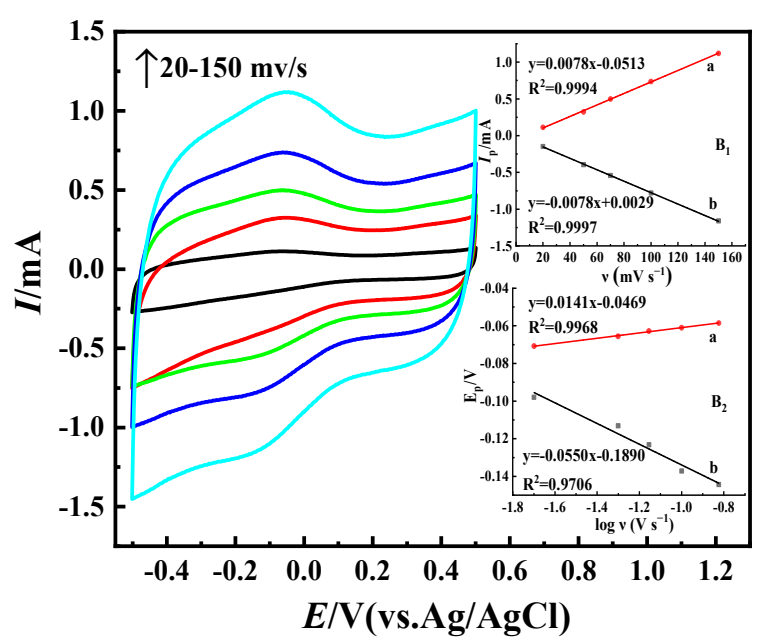

(b)

Figure 8. (a) CVs of Nafion/GOx/OMC-COOH at different scan rates $\left(20-150 \mathrm{mV} \cdot \mathrm{s}^{-1}\right)$; insets $\left(\mathrm{A}_{1}\right.$ and $\left.\mathrm{A}_{2}\right)$ are plots of anodic and cathodic peak currents vs. scan rate and peak potentials vs. log-scan rates, respectively. (b) CVs of Nafion/GOx$\mathrm{NH}_{2} / \mathrm{OMC}-\mathrm{COOH}$ at different scan rates $\left(20-200 \mathrm{mV} \cdot \mathrm{s}^{-1}\right)$; insets $\left(\mathrm{B}_{1}\right.$ and $\left.\mathrm{B}_{2}\right)$ are plots of anodic and cathodic peak currents vs. scan rate and peak potentials vs. log-scan rates, respectively.

As shown in Figure $8\left(A_{2}\right.$ and $\left.B_{2}\right)$, peak currents $\left(i_{p a}\right.$ and $\left.i_{p c}\right)$ and peak potentials $\left(E_{p a}\right.$ and $\left.E_{p c}\right)$ were plotted against $v$. A line starting from the origin ( $i_{p} v s . v$ plot) illustrates that the adsorption of enzymes on biological anodes controls the phenomenon of electron transfer [63]. Through the Laviron theory and its equation [64], the charge transfer coefficient, $\alpha$, and apparent electron transfer rate constant, $k_{s}$ can be calculated:

$$
k_{s}=m n v F / R T
$$

where $n$ is the number of transferred electrons $(n=2), v$ is the scanning rate $\left(50 \mathrm{mV} \cdot \mathrm{s}^{-1}\right), R$ is the universal gas constant $\left(8.314 \mathrm{~J} \cdot \mathrm{mol}^{-1} \cdot \mathrm{K}^{-1}\right), T$ is the room temperature $(298.15 \mathrm{~K})$, and $m$ is a constant related to peak potential separation $\Delta \mathrm{E}_{\mathrm{p}}$ (m is 0.69 in this work, since the $\mathrm{n} \Delta \mathrm{E}_{\mathrm{p}}$ value is $\sim 47.52 \mathrm{mV}$ ) [64]. The charge transfer coefficients $\alpha$ of Nafion/GOx/OMC-COOH and Nafion/GOx- $\mathrm{NH}_{2} / \mathrm{OMC}-\mathrm{COOH}$ are 0.41 and 0.54 , respectively. The $\alpha$ increases as the number of immobilized enzymes increases, starting from 0.41 (Nafion/GOx/OMC-COOH) up to approximately 0.54 (Nafion/GOx- $\mathrm{NH}_{2} / \mathrm{OMC}-\mathrm{COOH}$ ) [65]. The calculated $k_{s}$ of Nafion/GOx- $\mathrm{NH}_{2} / \mathrm{OMC}-\mathrm{COOH}$ was $2.54 \mathrm{~s}^{-1}$ which is much larger than the rate constant of GOx adsorbed on the OMC-COOH electrode $\left(1.83 \mathrm{~s}^{-1}\right)$. These results further suggest that the enzyme ammoniation can promote the electron exchange between the active site of GOx and the electrode [58]. This finding implies that the anodic reaction (GOx oxidation) is preferable.

\section{Discussion}

\subsection{Effects of GOx Amination}

Our results indicate that chemical amination of enzymes can significantly affect the immobilization and activity of GOx on OMC-COOH. The activity of immobilized aminated GOx modified with 10 mM DEC increased by 16.58\% (as shown in Figure 1). The driving 
force of the immobilization of aminated GOx on $\mathrm{OMC}-\mathrm{COOH}$ is not the reactivity of a single residue, but the density of reactive groups on the protein surface (amination can change the number of amino groups on the protein surface) [66]. The results show that the chemical amination of enzymes can significantly affect the quantity of non-modified GOx and aminated GOx fixed on OMC-COOH. The modification enriches the enzyme surface with low-pK amino groups [44,67], making the enzyme more reactive against $\mathrm{OMC}-\mathrm{COOH}$, and allowing the enzymes to be fixed on $\mathrm{OMC}-\mathrm{COOH}$ at $\mathrm{pH}$ of $7[14,20]$. The number of highly reactive amino groups can also promote immobilization, depending on the density of the reactive groups of the support and the enzyme [66]. Therefore, amination of the enzyme slightly changes the properties of the enzyme, but greatly improves the immobilization [22].

\subsection{Improved Characteristics of the Bioelectrode}

OMCs are ideal substrates for the deposition of biomolecules because of their large surface area, high aspect ratio, and adjustable specificity of enzyme adsorption [68]. The OMCs were previously oxidized to introduce carboxylic groups on their defect sites in order to ensure their efficient adsorption to the enzyme molecule [23]. EDA was used to increase the number of primary amino groups on the GOx surface, thereby increasing the reaction between the surface amino groups produced by amination and the carboxyl groups produced by the oxidation of OMC to improve the efficiency of fixation [69]. A part of the OMC-COOH structure extends in a radial manner, which can increase the specific surface area of the composite material and improve its mechanical strength [70]. This structural optimization can effectively enhance the electron transfer between the enzyme protein structure and the electrode $[69,71]$. The result indicates the superiority of Nafion/GOx-NH$/ 2$ OMC-COOH electrodes over Nafion/GOx/OMC-COOH electrodes. This performance is due to the coupling between the carboxyl group of carboxylated OMC and the amino group of aminated GOx, while retaining the structure of GOx and its catalytic effect [23]. Meanwhile, the reason that GOx can perform effective electron transfer on carbon nanomaterial electrodes is possibly because part of the protein conformational rearrangement occurs during the electron transfer process [5,8]. The changes caused by this adsorption $[5,72]$ may be due to the conformational changes of GOx in the microenvironment that lead to the active site of GOx being close to the electrode [8].

In addition, the integration of the $\mathrm{CV}$ peak can calculate the total charge (Q) of the electrode, which is used to evaluate the electrical activity of the immobilized enzyme. The value of $\Gamma$ is calculated by the formula $\Gamma=Q / n F A$, where $\Gamma$ is the surface coverage of the enzyme electrode, $Q$ is the total charge of the electrode, $F$ is the Faraday constant, $n$ is the number of electrons transferred, and $A$ is the electrode area $\left(1 \mathrm{~cm}^{2}\right)$ [73]. The surface coverage $(\Gamma)$ of electroactive non-modified GOx in Nafion/GOx/OMC-COOH and GOx- $\mathrm{NH}_{2}$ in Nafion/GOx-NH $/$ OMC-COOH was $2.41 \times 10^{-9} \mathrm{~mol} \cdot \mathrm{cm}^{-2}$ and $2.91 \times 10^{-9} \mathrm{~mol} \cdot \mathrm{cm}^{-2}$, respectively. These values are far greater than that of monolayer GOx covering the surface of the bare electrode $\left(2.86 \times 10^{-12} \mathrm{~mol} \cdot \mathrm{cm}^{-2}\right)$ [74], indicating that the enzyme achieves a multilayer and three-dimensional coverage of $\mathrm{OMC}-\mathrm{COOH}$. After calculation, the enzyme surface coverage of the Nafion/GOx- $\mathrm{NH}_{2} / \mathrm{OMC}-\mathrm{COOH}$ electrode was $20.72 \%$ higher than that of the Nafion/GOx/OMC-COOH electrode. In addition, the surface coverage of the Nafion/GOx- $\mathrm{NH}_{2} / \mathrm{OMC}-\mathrm{COOH}$ electrode was wider than that of GOx coated on the surface of nickel oxide/hydroxide $\left(\mathrm{NiO} / \mathrm{Ni}(\mathrm{OH})_{2}\right)\left(1.43 \times 10^{-10} \mathrm{~mol} \cdot \mathrm{cm}^{-2}\right)$ [75], Nafion/GOxCoS-MWCNTs/GCE $\left(2.97 \times 10^{-11} \mathrm{~mol} \cdot \mathrm{cm}^{-2}\right)$ [76], and Nafion/GOx/ERGO-PLL/GCE $\left(1.64 \times 10^{-11} \mathrm{~mol} \cdot \mathrm{cm}^{-2}\right)$ electrodes [4]. These calculation results show that, compared to the Nafion/GOx/OMC-COOH and other electrodes, the Nafion/GOx- $\mathrm{NH}_{2} / \mathrm{OMC}-\mathrm{COOH}$ electrode has an advantage in effective electron transfer [73]. Above all, the amination treatment could increase the enzyme surface coverage and, thus, improve the effective electron transfer efficiency for the bioelectrode.

The work in this paper and the work in other references have been compared, the results of which are shown in Table 2. Compared with other bioelectrodes constructed 
with GOx, our electrode exhibits a higher current, and the GOx surface coverage and apparent electron transfer rate constant are higher than those of other electrodes. The results show that the chemical amination of enzymes can increase the enzyme loading of the bioelectrode, accelerate the electron transfer rate, and achieve the purpose of improving electrode performance.

Table 2. Comparison between various GOx bioelectrodes.

\begin{tabular}{cccccc}
\hline Electrode & $\begin{array}{c}\text { Anodic Peak } \\
\text { Current }\end{array}$ & $\begin{array}{c}\text { Reduction } \\
\text { Peak Current }\end{array}$ & GOx Surface Coverage $(\boldsymbol{\Gamma})$ & $\boldsymbol{k}_{\boldsymbol{s}}$ & References \\
\hline Nafion/GOx-NH$/ \mathrm{OMC}-\mathrm{COOH}$ & $0.324 \mathrm{~mA}$ & $-0.394 \mathrm{~mA}$ & $2.91 \times 10^{-9} \mathrm{~mol} \cdot \mathrm{cm}^{-2}$ & $2.54 \mathrm{~s}^{-1}$ & This study \\
\hline $\mathrm{GC} / \mathrm{TiO}_{2}-\mathrm{IOSL} / \mathrm{GOD}$ & $0.020 \mathrm{~mA}$ & $-0.022 \mathrm{~mA}$ & $1.23 \times 10^{-9} \mathrm{~mol}^{-\mathrm{cm}^{-2}}$ & $1.74 \mathrm{~s}^{-1}$ & {$[77]$} \\
\hline $\mathrm{RGO}-\mathrm{AuNPs} / \mathrm{PNR} / \mathrm{GOx}$ & $0.006 \mathrm{~mA}$ & $-0.012 \mathrm{~mA}$ & $3.06 \times 10^{-9} \mathrm{~mol} \cdot \mathrm{cm}^{-11}$ & $1.73 \mathrm{~s}^{-1}$ & {$[59]$} \\
\hline $\mathrm{GOD} / \mathrm{HRP} / \mathrm{Ag} / \mathrm{CNT} / \mathrm{ITO}$ & $0.022 \mathrm{~mA}$ & $-0.008 \mathrm{~mA}$ & $3.52 \times 10^{-10} \mathrm{~mol}^{-1} \mathrm{~cm}^{-2}$ & $1.76 \mathrm{~s}^{-1}$ & {$[78]$} \\
\hline $\mathrm{GCE} / \mathrm{MnO}_{2}-\mathrm{G} / \mathrm{PTA} / \mathrm{Frt} / \mathrm{GOx}$ & $0.120 \mathrm{~mA}$ & $-0.180 \mathrm{~mA}$ & $9.7 \times 10^{-10} \mathrm{~mol}_{\mathrm{cm}}^{-2}$ & $1.96 \mathrm{~s}^{-1}$ & {$[79]$} \\
\hline
\end{tabular}

\section{Conclusions}

Amination could be applied as a promising modification method for constructing effective glucose oxidase bioelectrodes, because it allows the enzyme to be more stable and efficiently immobilized on the mesoporous carbon material activated with carboxyl groups. In comparison to the non-modified enzyme, amination and the immobilization process can improve the electrochemical properties of the bioelectrode, such as its apparent electron transfer rate constant and charge-transfer coefficient.

Author Contributions: Conceptualization, X.Y. and M.Y.; methodology, X.Y. and C.L.; software, C.L.; validation, C.L., X.Y. and M.Y.; formal analysis, C.L. and X.Y.; investigation, C.L.; resources, C.L. and X.Y.; data curation, C.L.; writing-original draft preparation, C.L. and X.Y.; writing-review and editing, X.Y., S.L. and M.Y.; visualization, Q.H., S.L. and Z.W.; supervision, Q.H. and X.Y.; project administration, X.Y. and S.L.; funding acquisition, X.Y. and S.L. All authors have read and agreed to the published version of the manuscript.

Funding: This study was supported by the National Key Research and Development Project (Grant No.2018YFA0902500), the Natural Science Foundation of Guangdong Province (Grant No. 2018A030313139, 2021A1515012557), the Joint R\&D Project of Shenzhen-Hong Kong Innovation (Grant No. SGLH20180622152010394), and the Hong Kong Innovation and Technology Commission TCFS (GHP/087/18SZ), and sponsored by the Shenzhen Taifeng East Marine Biotechnology Co. Ltd., Natural Science Foundation of Shenzhen (Grant No. KQJSCX20180328093806045), the Shenzhen Science and Technology Application Demonstration Project (Grant No. KJYY20180201180253571), the Special Funds for Science, Technology, Innovation, and Industrial Development of Shenzhen Dapeng New District (Grand No.KJYF202001-27), and Shenzhen Sustainable Development Project (Grand No.KCXFZ20201221173211033).

Institutional Review Board Statement: This study did not involve humans or animals.

Informed Consent Statement: Not applicable.

Data Availability Statement: The data presented in this study are contained within the article.

Conflicts of Interest: The authors declare no conflict of interest.

\section{References}

1. Li, J.; Wang, Y.-B.; Qiu, J.-D.; Sun, D.-C.; Xia, X.-H. Biocomposites of covalently linked glucose oxidase on carbon nanotubes for glucose biosensor. Anal. Bioanal. Chem. 2005, 383, 918-922. [CrossRef] [PubMed]

2. Liu, Q.; Lu, X.; Li, J.; Yao, X.; Li, J. Direct electrochemistry of glucose oxidase and electrochemical biosensing of glucose on quantum dots/carbon nanotubes electrodes. Biosens. Bioelectron. 2007, 22, 3203-3209. [CrossRef] [PubMed]

3. Tasis, D.; Tagmatarchis, N.; Bianco, A.; Prato, M. Chemistry of Carbon Nanotubes. Chem. Rev. 2006, 106, 1105-1136. [CrossRef] [PubMed] 
4. Zhang, D.; Chen, X.; Ma, W.; Yang, T.; Li, D.; Dai, B.; Zhang, Y. Direct electrochemistry of glucose oxidase based on one step electrodeposition of reduced graphene oxide incorporating polymerized l-lysine and its application in glucose sensing. Mater. Sci. Eng. C 2019, 104, 109880. [CrossRef] [PubMed]

5. Zhao, H.-Z.; Sun, J.-J.; Song, J.; Yang, Q.-Z. Direct electron transfer and conformational change of glucose oxidase on carbon nanotube-based electrodes. Carbon 2010, 48, 1508-1514. [CrossRef]

6. Beissenhirtz, M.K.; Scheller, F.W.; Stöcklein, W.F.M.; Kurth, D.G.; Möhwald, H.; Lisdat, F. Electroactive Cytochrome c Multilayers within a Polyelectrolyte Assembly. Angew. Chem. Int. Ed. 2004, 43, 4357-4360. [CrossRef]

7. Marcus, R.A.; Sutin, N. Electron transfers in chemistry and biology. Biochim. Biophys. Acta (BBA)—Rev. Bioenerg. 1985, 811, 265-322. [CrossRef]

8. Liu, Y.; Wang, M.; Zhao, F.; Xu, Z.; Dong, S. The direct electron transfer of glucose oxidase and glucose biosensor based on carbon nanotubes/chitosan matrix. Biosens. Bioelectron. 2005, 21, 984-988. [CrossRef]

9. Deng, C.; Chen, J.; Chen, X.; Xiao, C.; Nie, L.; Yao, S. Direct electrochemistry of glucose oxidase and biosensing for glucose based on boron-doped carbon nanotubes modified electrode. Biosens. Bioelectron. 2008, 23, 1272-1277. [CrossRef]

10. Kang, X.; Mai, Z.; Zou, X.; Cai, P.; Mo, J. A novel glucose biosensor based on immobilization of glucose oxidase in chitosan on a glassy carbon electrode modified with gold-platinum alloy nanoparticles/multiwall carbon nanotubes. Anal. Biochem. 2007, 369, 71-79. [CrossRef]

11. Ren, Q.; Feng, L.; Fan, R.; Ge, X.; Sun, Y. Water-dispersible triethylenetetramine-functionalized graphene: Preparation, characterization and application as an amperometric glucose sensor. Mater. Sci. Eng. C 2016, 68, 308-316. [CrossRef]

12. Hitaishi, V.P.; Clement, R.; Bourassin, N.; Baaden, M.; De Poulpiquet, A.; Sacquin-Mora, S.; Ciaccafava, A.; Lojou, E. Controlling Redox Enzyme Orientation at Planar Electrodes. Catalysts 2018, 8, 192. [CrossRef]

13. Abian, O.; Grazú, V.; Hermoso, J.; González, R.; García, J.L.; Fernández-Lafuente, R.; Guisán, J.M. Stabilization of penicillin G acylase from Escherichia coli: Site-directed mutagenesis of the protein surface to increase multipoint covalent attachment. Appl. Environ. Microbiol. 2004, 70, 1249-1251. [CrossRef]

14. López-Gallego, F.; Montes, T.; Fuentes, M.; Alonso, N.; Grazu, V.; Betancor, L.; Guisán, J.M.; Fernández-Lafuente, R. Improved stabilization of chemically aminated enzymes via multipoint covalent attachment on glyoxyl supports. J. Biotechnol. 2005, 116, 1-10. [CrossRef]

15. Mazurenko, I.; Hitaishi, V.P.; Lojou, E. Recent advances in surface chemistry of electrodes to promote direct enzymatic bioelectrocatalysis. Curr. Opin. Electrochem. 2020, 19, 113-121. [CrossRef]

16. Meder, F.; Daberkow, T.; Treccani, L.; Wilhelm, M.; Schowalter, M.; Rosenauer, A.; Mädler, L.; Rezwan, K. Protein adsorption on colloidal alumina particles functionalized with amino, carboxyl, sulfonate and phosphate groups. Acta Biomater. 2012, 8 , 1221-1229. [CrossRef] [PubMed]

17. Meder, F.; Hintz, H.; Koehler, Y.; Schmidt, M.M.; Treccani, L.; Dringen, R.; Rezwan, K. Adsorption and Orientation of the Physiological Extracellular Peptide Glutathione Disulfide on Surface Functionalized Colloidal Alumina Particles. J. Am. Chem. Soc. 2013, 135, 6307-6316. [CrossRef] [PubMed]

18. Gessner, A.; Waicz, R.; Lieske, A.; Paulke, B.R.; Mäder, K.; Müller, R.H. Nanoparticles with decreasing surface hydrophobicities: Influence on plasma protein adsorption. Int. J. Pharm. 2000, 196, 245-249. [CrossRef]

19. Olloqui-Sariego, J.L.; Calvente, J.J.; Andreu, R. Immobilizing Redox Enzymes at Mesoporous and Nanoestructured Electrodes. Curr. Opin. Electrochem. 2020, 26, 100658. [CrossRef]

20. Fernandez-Lorente, G.; Godoy, C.A.; Mendes, A.A.; Lopez-Gallego, F.; Grazu, V.; de las Rivas, B.; Palomo, J.M.; Hermoso, J.; Fernandez-Lafuente, R.; Guisan, J.M. Solid-Phase Chemical Amination of a Lipase from Bacillus thermocatenulatus To Improve Its Stabilization via Covalent Immobilization on Highly Activated Glyoxyl-Agarose. Biomacromolecules 2008, 9, 2553-2561. [CrossRef]

21. Ashjari, M.; Mohammadi, M.; Badri, R. Chemical amination of Rhizopus oryzae lipase for multipoint covalent immobilization on epoxy-functionalized supports: Modulation of stability and selectivity. J. Mol. Catal. B Enzym. 2015, 115, 128-134. [CrossRef]

22. Rodrigues, R.C.; Godoy, C.A.; Volpato, G.; Ayub, M.A.Z.; Fernandez-Lafuente, R.; Guisan, J.M. Immobilization-stabilization of the lipase from Thermomyces lanuginosus: Critical role of chemical amination. Process Biochem. 2009, 44, 963-968. [CrossRef]

23. Othman, A.M.; Wollenberger, U. Amperometric biosensor based on coupling aminated laccase to functionalized carbon nanotubes for phenolics detection. Int. J. Biol. Macromol. 2020, 153, 855-864. [CrossRef] [PubMed]

24. Kjeang, E.; Michel, R.; Harrington, D.A.; Djilali, N.; Sinton, D. A Microfluidic Fuel Cell with Flow-Through Porous Electrodes. J. Am. Chem. Soc. 2008, 130, 4000-4006. [CrossRef]

25. Yang, X.; Ma, X.; Wang, K.; Wu, D.; Lei, Z.; Feng, C. Eighteen-month assessment of 3D graphene oxide aerogel-modified 3D graphite fiber brush electrode as a high-performance microbial fuel cell anode. Electrochim. Acta 2016, 210, 846-853. [CrossRef]

26. Aldalbahi, A.; Rahaman, M.; Almoiqli, M.; Hamedelniel, A.; Alrehaili, A. Single-Walled Carbon Nanotube (SWCNT) Loaded Porous Reticulated Vitreous Carbon (RVC) Electrodes Used in a Capacitive Deionization (CDI) Cell for Effective Desalination. Nanomaterials 2018, 8, 527. [CrossRef]

27. Mishra, A.; Shetti, N.P.; Basu, S.; Reddy, K.R.; Aminabhavi, T.M. Carbon Cloth-based Hybrid Materials as Flexible Electrochemical Supercapacitors. ChemElectroChem 2019, 6, 5771-5786. [CrossRef]

28. Mazurenko, I.; Monsalve, K.; Infossi, P.; Giudici-Orticoni, M.-T.; Topin, F.; Mano, N.; Lojou, E. Impact of substrate diffusion and enzyme distribution in 3D-porous electrodes: A combined electrochemical and modelling study of a thermostable $\mathrm{H}_{2} / \mathrm{O}_{2}$ enzymatic fuel cell. Energy Environ. Sci. 2017, 10, 1966-1982. [CrossRef] 
29. Mendes, T.P.P.; Lobón, G.S.; Lima, L.A.S.; Guerra, N.K.M.; Carvalho, G.A.; Freitas, E.M.M.; Pinto, M.C.X.; Pereira, I.; Vaz, B.G. Mass spectrometry-based biosensing using pencil graphite rods. Microchem. J. 2021, 164, 106077. [CrossRef]

30. Arlyapov, V.A.; Khar'kova, A.S.; Abramova, T.N.; Kuznetsova, L.S.; Ilyukhina, A.S.; Zaitsev, M.G.; Machulin, A.V.; Reshetilov, A.N. A Hybrid Redox-Active Polymer Based on Bovine Serum Albumin, Ferrocene, Carboxylated Carbon Nanotubes, and Glucose Oxidase. J. Anal. Chem. 2020, 75, 1189-1200. [CrossRef]

31. Wang, J. Nanomaterial-based electrochemical biosensors. Analyst 2005, 130, 421-426. [CrossRef] [PubMed]

32. Kumar, R.; Bhuvana, T.; Mishra, G.; Sharma, A. A polyaniline wrapped aminated graphene composite on nickel foam as three-dimensional electrodes for enzymatic microfuel cells. RSC Adv. 2016, 6, 73496-73505. [CrossRef]

33. You, H.; Mu, Z.; Zhao, M.; Zhou, J.; Chen, Y.; Bai, L. Voltammetric aptasensor for sulfadimethoxine using a nanohybrid composed of multifunctional fullerene, reduced graphene oxide and Pt@Au nanoparticles, and based on direct electron transfer to the active site of glucose oxidase. Microchim. Acta 2018, 186, 1. [CrossRef]

34. Davis, J.J.; Green, M.L.H.; Allen, O.; Hill, H.; Leung, Y.C.; Sadler, P.J.; Sloan, J.; Xavier, A.V.; Tsang, S.C. The immobilisation of proteins in carbon nanotubes. Inorg. Chim. Acta 1998, 272, 261-266. [CrossRef]

35. Zhang, K.; Zhou, H.; Hu, P.; Lu, Q. The direct electrochemistry and bioelectrocatalysis of nitrate reductase at a gold nanoparticles/aminated graphene sheets modified glassy carbon electrode. RSC Adv. 2019, 9, 37207-37213. [CrossRef]

36. Meder, F.; Kaur, S.; Treccani, L.; Rezwan, K. Controlling Mixed-Protein Adsorption Layers on Colloidal Alumina Particles by Tailoring Carboxyl and Hydroxyl Surface Group Densities. Langmuir 2013, 29, 12502-12510. [CrossRef]

37. Lopes, I.; Piao, L.; Stievano, L.; Lambert, J.-F. Adsorption of Amino Acids on Oxide Supports: A Solid-State NMR Study of Glycine Adsorption on Silica and Alumina. J. Phys. Chem. C 2009, 113, 18163-18172. [CrossRef]

38. Thyparambil, A.A.; Wei, Y.; Latour, R.A. Determination of Peptide-Surface Adsorption Free Energy for Material Surfaces Not Conducive to SPR or QCM using AFM. Langmuir 2012, 28, 5687-5694. [CrossRef]

39. Soliman, W.; Bhattacharjee, S.; Kaur, K. Adsorption of an Antimicrobial Peptide on Self-Assembled Monolayers by Molecular Dynamics Simulation. J. Phys. Chem. B 2010, 114, 11292-11302. [CrossRef]

40. Lv, C.; Li, S.; Liu, L.; Zhu, X.; Yang, X. Enhanced Electrochemical Characteristics of the Glucose Oxidase Bioelectrode Constructed by Carboxyl-Functionalized Mesoporous Carbon. Sensors 2020, 20, 3365. [CrossRef]

41. Vinu, A.; Hossian, K.Z.; Srinivasu, P.; Miyahara, M.; Anandan, S.; Gokulakrishnan, N.; Mori, T.; Ariga, K.; Balasubramanian, V.V. Carboxy-mesoporous carbon and its excellent adsorption capability for proteins. J. Mater. Chem. 2007, 17, 1819-1825. [CrossRef]

42. Deng, S.; Jian, G.; Lei, J.; Hu, Z.; Ju, H. A glucose biosensor based on direct electrochemistry of glucose oxidase immobilized on nitrogen-doped carbon nanotubes. Biosens. Bioelectron. 2009, 25, 373-377. [CrossRef]

43. Afshar, H.A.; Ghaee, A. Preparation of aminated chitosan/alginate scaffold containing halloysite nanotubes with improved cell attachment. Carbohydr. Polym. 2016, 151, 1120-1131. [CrossRef] [PubMed]

44. de Morais Júnior, W.G.; Terrasan, C.R.F.; Fernández-Lorente, G.; Guisán, J.M.; Ribeiro, E.J.; de Resende, M.M.; Pessela, B.C. Solidphase amination of Geotrichum candidum lipase: Ionic immobilization, stabilization and fish oil hydrolysis for the production of Omega-3 polyunsaturated fatty acids. Eur. Food Res. Technol. 2017, 243, 1375-1384. [CrossRef]

45. Rodrigues, R.C.; Barbosa, O.; Ortiz, C.; Berenguer-Murcia, Á.; Torres, R.; Fernandez-Lafuente, R. Amination of enzymes to improve biocatalyst performance: Coupling genetic modification and physicochemical tools. RSC Adv. 2014, 4, 38350-38374. [CrossRef]

46. Hernandez, K.; Fernandez-Lafuente, R. Control of protein immobilization: Coupling immobilization and site-directed mutagenesis to improve biocatalyst or biosensor performance. Enzym. Microb. Technol. 2011, 48, 107-122. [CrossRef] [PubMed]

47. Rosenbohm, C.; Lundt, I.; Christensen, T.I.E.; Young, N.G. Chemically methylated and reduced pectins: Preparation, characterisation by $1 \mathrm{H}$ NMR spectroscopy, enzymatic degradation, and gelling properties. Carbohydr. Res. 2003, 338, 637-649. [CrossRef]

48. Hoare, D.G.; Olson, A.; Koshland, D.E. The reaction of hydroxamic acids with water-soluble carbodiimides. A lossen rearrangement. J. Am. Chem. Soc. 1968, 90, 1638-1643. [CrossRef]

49. Spalding, K.; Bonnier, F.; Bruno, C.; Blasco, H.; Board, R.; Benz-de Bretagne, I.; Byrne, H.J.; Butler, H.J.; Chourpa, I.; Radhakrishnan, P.; et al. Enabling quantification of protein concentration in human serum biopsies using attenuated total reflectance-Fourier transform infrared (ATR-FTIR) spectroscopy. Vib. Spectrosc. 2018, 99, 50-58. [CrossRef]

50. Movasaghi, Z.; Rehman, S.; ur Rehman, D.I. Fourier transform infrared (FTIR) spectroscopy of biological tissues. Appl. Spectrosc. Rev. 2008, 43, 134-179. [CrossRef]

51. Schmidt, M.P.; Martínez, C.E. Kinetic and Conformational Insights of Protein Adsorption onto Montmorillonite Revealed Using in Situ ATR-FTIR/2D-COS. Langmuir 2016, 32, 7719-7729. [CrossRef] [PubMed]

52. Andrade, J.; Pereira, C.G.; de Almeida Junior, J.C.; Viana, C.C.R.; de Oliveira Neves, L.N.; da Silva, P.H.F.; Bell, M.J.V.; de Carvalho dos Anjos, V. FTIR-ATR determination of protein content to evaluate whey protein concentrate adulteration. LWT 2019, 99, 166-172. [CrossRef]

53. Barth, A.; Zscherp, C. What vibrations tell about proteins. Q. Rev. Biophys. 2002, 35, 369-430. [CrossRef] [PubMed]

54. Grdadolnik, J.; Maréchal, Y. Bovine serum albumin observed by infrared spectrometry. I. Methodology, structural investigation, and water uptake. Biopolymers 2001, 62, 40-53. [CrossRef] 
55. Shrestha, B.K.; Ahmad, R.; Mousa, H.M.; Kim, I.-G.; Kim, J.I.; Neupane, M.P.; Park, C.H.; Kim, C.S. High-performance glucose biosensor based on chitosan-glucose oxidase immobilized polypyrrole/Nafion/functionalized multi-walled carbon nanotubes bio-nanohybrid film. J. Colloid Interface Sci. 2016, 482, 39-47. [CrossRef] [PubMed]

56. Tian, K.; Liu, H.; Dong, Y.; Chu, X.; Wang, S. Amperometric detection of glucose based on immobilizing glucose oxidase on g- $\mathrm{C}_{3} \mathrm{~N}_{4}$ nanosheets. Colloids Surf. A Physicochem. Eng. Asp. 2019, 581, 123808. [CrossRef]

57. Sağlam, Ö.; Kızılkaya, B.; Uysal, H.; Dilgin, Y. Biosensing of glucose in flow injection analysis system based on glucose oxidasequantum dot modified pencil graphite electrode. Talanta 2016, 147, 315-321. [CrossRef]

58. Wang, K.; Yang, H.; Zhu, L.; Ma, Z.; Xing, S.; Lv, Q.; Liao, J.; Liu, C.; Xing, W. Direct electron transfer and electrocatalysis of glucose oxidase immobilized on glassy carbon electrode modified with Nafion and mesoporous carbon FDU-15. Electrochim. Acta 2009, 54, 4626-4630. [CrossRef]

59. Mazar, F.M.; Alijanianzadeh, M.; Molaeirad, A.; Heydari, P. Development of Novel Glucose oxidase Immobilization on Graphene/Gold nanoparticles/Poly Neutral red modified electrode. Process Biochem. 2017, 56, 71-80. [CrossRef]

60. Terse-Thakoor, T.; Komori, K.; Ramnani, P.; Lee, I.; Mulchandani, A. Electrochemically Functionalized Seamless ThreeDimensional Graphene-Carbon Nanotube Hybrid for Direct Electron Transfer of Glucose Oxidase and Bioelectrocatalysis. Langmuir 2015, 31, 13054-13061. [CrossRef]

61. Jędrzak, A.; Rębiś, T.; Klapiszewski, Ł.; Zdarta, J.; Milczarek, G.; Jesionowski, T. Carbon paste electrode based on functional GOx/silica-lignin system to prepare an amperometric glucose biosensor. Sens. Actuators B Chem. 2018, 256, 176-185. [CrossRef]

62. Amatatongchai, M.; Sroysee, W.; Chairam, S.; Nacapricha, D. Amperometric flow injection analysis of glucose using immobilized glucose oxidase on nano-composite carbon nanotubes-platinum nanoparticles carbon paste electrode. Talanta 2017, 166, 420-427. [CrossRef]

63. Saravanan, N.; Mayuri, P.; Kumar, A.S. Improved Electrical Wiring of Glucose Oxidase Enzyme with an in-Situ Immobilized $\mathrm{Mn}\left(1,10\right.$-Phenanthroline ${ }_{2} \mathrm{Cl}_{2}$-Complex/Multiwalled Carbon Nanotube-Modified Electrode Displaying Superior Performance to Os-Complex for High-Current Sensitivity Bioelectrocatalytic and Biofuel Cell Applications. ACS Appl. Bio Mater. 2018, 1, 1758-1767.

64. Laviron, E. General expression of the linear potential sweep voltammogram in the case of diffusionless electrochemical systems. J. Electroanal. Chem. Interfacial Electrochem. 1979, 101, 19-28. [CrossRef]

65. Hess, A.; Roode-Gutzmer, Q.; Heubner, C.; Schneider, M.; Michaelis, A.; Bobeth, M.; Cuniberti, G. Determination of state of charge-dependent asymmetric Butler-Volmer kinetics for $\mathrm{LixCoO}_{2}$ electrode using GITT measurements. J. Power Sources 2015, 299, 156-161. [CrossRef]

66. Mateo, C.; Abian, O.; Bernedo, M.; Cuenca, E.; Fuentes, M.; Fernandez-Lorente, G.; Palomo, J.M.; Grazu, V.; Pessela, B.C.C.; Giacomini, C.; et al. Some special features of glyoxyl supports to immobilize proteins. Enzym. Microb. Technol. 2005, 37, 456-462. [CrossRef]

67. Fernandez-Lafuente, R.; Rosell, C.M.; Rodriguez, V.; Santana, C.; Soler, G.; Bastida, A.; Guisán, J.M. Preparation of activated supports containing low $\mathrm{pK}$ amino groups. A new tool for protein immobilization via the carboxyl coupling method. Enzym. Microb. Technol. 1993, 15, 546-550. [CrossRef]

68. Lu, F.; Gu, L.; Meziani, M.J.; Wang, X.; Luo, P.G.; Veca, L.M.; Cao, L.; Sun, Y.-P. Advances in Bioapplications of Carbon Nanotubes. Adv. Mater. 2009, 21, 139-152. [CrossRef]

69. Othman, A.M.; González-Domínguez, E.; Sanromán, Á.; Correa-Duarte, M.; Moldes, D. Immobilization of laccase on functionalized multiwalled carbon nanotube membranes and application for dye decolorization. RSC Adv. 2016, 6, 114690-114697. [CrossRef]

70. González-Domínguez, E.; Comesaña-Hermo, M.; Mariño-Fernández, R.; Rodríguez-González, B.; Arenal, R.; Salgueiriño, V.; Moldes, D.; Othman, A.M.; Pérez-Lorenzo, M.; Correa-Duarte, M.A. Hierarchical Nanoplatforms for High-Performance Enzyme Biocatalysis under Denaturing Conditions. ChemCatChem 2016, 8, 1264-1268. [CrossRef]

71. Lopez, R.J.; Babanova, S.; Ulyanova, Y.; Singhal, S.; Atanassov, P. Improved Interfacial Electron Transfer in Modified Bilirubin Oxidase Biocathodes. ChemElectroChem 2014, 1, 241-248. [CrossRef]

72. González-Gaitán, C.; Ruiz-Rosas, R.; Morallón, E.; Cazorla-Amorós, D. Effects of the surface chemistry and structure of carbon nanotubes on the coating of glucose oxidase and electrochemical biosensors performance. RSC Adv. 2017, 7, 26867-26878. [CrossRef]

73. Wang, L.; Bai, J.; Bo, X.; Zhang, X.; Guo, L. A novel glucose sensor based on ordered mesoporous carbon-Au nanoparticles nanocomposites. Talanta 2011, 83, 1386-1391. [CrossRef] [PubMed]

74. Jin-Zhong, X.; Jun-Jie, Z.; Qiang, W.; Zheng, H.; Hong-Yuan, C. Direct Electron Transfer between Glucose Oxidase and Multiwalled Carbon Nanotubes. Chin. J. Chem. 2003, 21, 1088-1091. [CrossRef]

75. Njoko, N.; Louzada, M.; Britton, J.; Khene, S.; Nyokong, T.; Mashazi, P. Bioelectrocatalysis and surface analysis of gold coated with nickel oxide/hydroxide and glucose oxidase towards detection of glucose. Colloids Surf. B Biointerfaces 2020, $190,110981$. [CrossRef]

76. Li, J.; Liu, Y.; Tang, X.; Xu, L.; Min, L.; Xue, Y.; Hu, X.; Yang, Z. Multiwalled carbon nanotubes coated with cobalt(II) sulfide nanoparticles for electrochemical sensing of glucose via direct electron transfer to glucose oxidase. Microchim. Acta 2020, 187, 80. [CrossRef] 
77. Haghighi, N.; Hallaj, R.; Salimi, A. Immobilization of glucose oxidase onto a novel platform based on modified TiO ${ }_{2}$ and graphene oxide, direct electrochemistry, catalytic and photocatalytic activity. Mater. Sci. Eng. C 2017, 73, 417-424. [CrossRef] [PubMed]

78. Lin, J.; He, C.; Zhao, Y.; Zhang, S. One-step synthesis of silver nanoparticles/carbon nanotubes/chitosan film and its application in glucose biosensor. Sens. Actuators B Chem. 2009, 137, 768-773. [CrossRef]

79. Mani, V.; Govindasamy, M.; Chen, S.-M.; Chen, T.-W.; Kumar, A.S.; Huang, S.-T. Core-shell heterostructured multiwalled carbon nanotubes@reduced graphene oxide nanoribbons/chitosan, a robust nanobiocomposite for enzymatic biosensing of hydrogen peroxide and nitrite. Sci. Rep. 2017, 7, 11910. [CrossRef] 